\title{
The overseas ophthalmologist in Britain
}

\section{Puvana Chandra}

It is important for Britain to keep its doors open for duly selected ophthalmologists to come, work, and train here

$\mathrm{D}$ octors from abroad have come to the shores of Britain for many years. Colonial connections and intellectual interest in pursuing postgraduate training are the main reasons why the wind blew in this direction. Moorfields was the mecca to many and taking a glimpse of "the Duke" (Sir Stewart Duke-Elder) was the ultimate ambition for those who had, by then, read all his volumes from cover to cover. Many came hoping to return home with long and impressive titles-FRCS and a DO to add some flavour-but some stayed on to reach various levels of responsibility in the National Health Service, especially at a time of reorganisation, when trained and experienced hands and eyes were needed, particularly in the periphery of service provision.

Courses and examinations are like the United Nations Assembly without the flags, but the accents help to identify the country they represent. Long chats about cricket at surgical oral examinations were not all that rare and the candidates often wondered why they failed at the end of what seemed to have been a very interesting discussion on whether a particular bowler was an off spinner or a leg spinner. There is also a steady trickle of trainees from the Antipodes, Europe, and the other side of the Atlantic, adding to the international flavour that British ophthalmology has always enjoyed.

On a more practical note, most trainees who come to the United Kingdom expect to be trained to a very high standard. This is despite most of them boasting to have done thousands of cataracts and other operations before reaching the shores of Britain, certainly more than the entries in the logbooks of local trainees. Some are so experienced that they claim to be able to operate with their eyes closed and imply that maybe with a bit more extra training, they can learn to operate with even the patients' eyes closed! Learning to detect anterior segment disorders with a torch certainly would have sharpened their clinical acumen and the vast cutting experience improved their dexterity but structured training with proper appraisals is what they all need and hoped for by joining the training schemes here.
Poor economic conditions, civil unrest, and discrimination based on ethnicity are becoming increasingly the reasons why migrant ophthalmologists land on the shores of Britain now. In general, they are made to feel that their decision is the right one but, at times, terms like "equal opportunity" and "British fair play" seem to be almost non-existent, ${ }^{1-4}$ like the faint flare and odd cell in the anterior chamber that a new trainee is trying to find in mild iritis. We all know that it is there, but one has to look at bit harder at times-“Thin, small bright beam under high magnification, doctor."

\section{Poor economic conditions, civil unrest, and discrimination based on ethnicity are becoming increasingly the reasons why migrant ophthalmologists land on the shores of Britain}

With multinational companies pushing their products very hard, and books and other learning materials becoming widely available on the web and in book shops, an average overseas ophthalmologist coming to Britain does not find the practice of ophthalmology all that different. However, language can be a hurdle both to the doctor and the patient but, in most instances, seems to be overcome very quickly. With satellite television and intense Hollywood blitz in all the developing countries, cultural shock on coming to Britain seems to be a thing of the past. In fact, most overseas doctors seem to know the latest story line of Coronation Street better than their British counterparts! The Royal College of Ophthalmologists has produced an excellent booklet ${ }^{5}$ giving all necessary advice with regard to the specialty as well as visa, employment, and other issues-as good as The Hitchhikers' Guide to the Galaxy. Most deaneries have produced handbooks on training in general for overseas qualified doctors. ${ }^{67}$

This, along with the induction day arranged especially for overseas doctors in many regions, makes life in general for many newcomers very much easier, and the only extra bit to master is the map of the underground to get around London with important stops being No 17 Cornwall Terrace, Moorfields, the GMC Office, and Oxford Street!

It appears that the United Kingdom needs more ophthalmologists within the next few years to meet certain targets that seem to have been plucked out of thin air, based perhaps purely on a desire to reduce waiting lists rather than by looking at supply and demand or staff level planning. Any overseas recruitment drive needs to be carefully planned. GMC registration and entry criteria for training career and specialist grades need to be fair and reflect the standards the royal colleges wish to maintain. While we do not have the equivalent of an Alice Springs or a Saskatchewan to adapt an area specific registration qualification or recruitment strategy, the royal colleges may need to put into place a very stringent assessment and appraisal programme to tide over any immediate extra need. In the long run, with more UK trained graduates electing to come into this specialty, British ophthalmology seems to have a bright and a self sufficient future. There are no figures available to give an indication of overseas qualified doctors in ophthalmology in the United Kingdom at present, but the dual sponsorship programme of the Royal College of Ophthalmologists has sponsored 130 doctors in the past 5 years. ${ }^{8}$

It is important for Britain to keep its doors open for duly selected ophthalmologists to come, work, and train here as it will no doubt continue to enhance the international standing of British ophthalmology, and provide highly trained ophthalmologists to many parts of the world. There is certainly a great demand for British trained overseas ophthalmologists, and during their training they do contribute immensely to the NHS and add flavour to this specialty, as they have done over the years. British ophthalmology has been tastefully spicy long before chicken tikka masala became a favourite dish in Britain.

The views expressed in this article are those of the author only.

Br J Ophthalmol 2002;86:255-257

\section{Author's affiliation}

K P Chandra, Chairman of the Overseas Doctors Training Committee, Royal College of Ophthalmologists

Correspondence to: H M Stanley Hospital Upper Denbigh Road, St Asaph LL17 ORS, North Wales, UK;

mr.puvana.chandra@cd-tr.wales.nhs.uk

\section{REFERENCES}

1 Esmail A Carnall D. Tackling racism in the NHS. BN 1997;314:618-9. 
2 Esmail A, Everington S. Racial discrimination against doctors from ethnic minorities. BM 1993;306:691-2.

3 Alleway L. Equal opportunities climb up the NHS agenda. Health Services Manpower Review 1987;13:12-3.

4 Bhopal R. Racism in medicine. BM 2001;322:1503-4
5 Royal College of Ophthalmologists. Guide to UK training in ophthalmology for overseas qualified doctors. London: RCO, Oct 2001.

6 Oxford Deanery guide to overseas doctors. March 2001.

7 University of Wales College of Medicine School of Postgraduate Medical \& Dental
Education Working in Wales Information for Overseas Doctors. April 1998.

8 Royal College of Ophthalmologists. Dual Sponsorship Pack for Overseas Doctors. London: Training Committee RCO, March 2000

\section{Visual attention lies within subcortex}

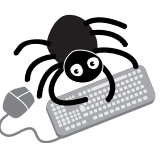

Please visit the British Journal of Ophthalmology

\section{website}

[www.bjophthalmol .com] for link to this full article.
$\mathrm{N}$ ew research from Germany shows that the subcortex of the brain affects selective visual attention. The discovery comes from a study by Fimm et al of 15 patients (10 with bleeding: five right sided and five left and five with infarction: three right and two left) with enclosed lesions exclusively in the subcortex, as determined by CT scanning on referral and confirmed by MRI 14-28 days after clinical onset.

Patients' performance in two computerised tests of visual attention-a searching and a detection test-compared with that of 200 controls against whom the tests had been standardised showed clear differences between those with right sided and those with left sided lesions. Most patients ( seven of eight) with right sided lesions were much slower or missed the target more often when scanning across a $5 \times 5$ matrix of squares when the target was in one of the left columns. However, their performance was as good as that of the controls in the test of visual hemineglect in detecting dots presented simultaneously in the left and right visual hemispace. Only two of seven patients with left sided lesions showed impairment in the searching or detection test.

The results confirm right brain dominance for spatial attention. This extends to the subcortex, independent of the cortex, and in these patients involves lesions in the basal ganglia, internal capsule, and thalamus-particularly the putamen and posterior limb of the internal capsule.

A Journal of Neurology Neurosurgery and Psychiatry 2001;71:652-657. 